\title{
Sosialisasi dan Pelatihan Pembuatan Alat Penyaring Air dengan Media Karbon Aktif Peruntukan Rumah Tangga
}

\author{
Widya Mulya ${ }^{1}$, Maslina $^{1}$, Lina Yuliana ${ }^{1}$ \\ $1^{*}$ Universitas Balikpapan \\ 1*widya@uniba-bpn.ac.id
}

\begin{abstract}
Abstrak
Pertumbuhan penduduk yang cukup pesat tentu membutuhkan penyediaan air bersih yang cukup besar. Kenaikan jumlah penduduk diikuti laju pemanfaatannya, beban pengotorannya juga bertambah. Berdasarkan data PDAM Kota Balikpapan (Desember 2011 - Februari 2012), Sungai yang saat ini dimanfaatkan, kekeruhan 20,50 - 73,30 NTU, total coliform 23 - > 2400 jumlah/100 ml. Hal tersebut mempengaruhi kualitas air baku yang akan diolah menjadi air minum. Beban pengotoran sungai bertambah, mengakibatkan bertambahnya beban pengolahan pada Instalasi Pengolahan Air, sehingga kualitas air yang diterima masyarakat terkadang menjadi menurun, pembuatan alat penyaring air peruntukan rumah tangga dapat menjadi solusi untuk mendapatkan kualitas air yang lebih baik. Alat penyaring air peruntukan rumah tangga dibuat dengan prinsip kerja filtrasi yang merupakan suatu proses penyaringan pada Instalasi Pengolahan Air yang dikelola oleh Perusahaan Air Minum. Filtrasi terjadi di bak filter, dimana di dalam bak berisi media butiran-butiran (granular) yang berfungsi menyaring partikel terlarut. Media penyaring yang digunakan pada Instalasi Pengolahan Air yaitu pasir silika. Prinsip kerja alat penyaring air dengan media karbon aktif peruntukan rumah tangga yaitu kecepatan penyaringan harus diatur sesuai kriteria perencanaan $(0,24-4,00 \mathrm{~m} / \mathrm{jam})$, media filter terdiri dari material bentuk granular $(0,21-0,86 \mathrm{~mm})$ yang mengisi atau tersusun pada aliran masuk hingga aliran keluar. Media penyaring air yang dapat digunakan peruntukkan rumah tangga yaitu karbon aktif dari tempurung kelapa. Karbon aktif mempunyai daya adsorpsi (penyerapan pada lapisan permukaan) yang tinggi sehingga dapat menguraikan senyawa mikro polutan, menurunkan zat besi dan mangan yang ada di dalam air.
\end{abstract}

Kata Kunci: Alat Penjernih Air, Karbon Aktif, Rumah Tangga.

\section{Abstract}

Rapid population growth certainly requires a large enough supply of clean water. The increase in population is followed by the rate of utilization, soiling impurities also increase. Based on Balikpapan city PDAM data (December 2011 - February 2012), the river currently being used, turbidity of 20,50 - 73,30 NTU, total coliform 23 - > 2400 amount/100 ml. This affects the quality of raw water that will be processed into drinking water. The burden of river pollution is increasing, resulting in an increased processing burden at the Water Treatment Plant, so that the quality of water received by the community sometimes decreases, making household water filtering equipment can be a solution to get better water quality. The water filter for household use is made with the workong principle of filtration which is a filtering process at the Water Treatment Plant managed by the Dinking Water Company. Filtration occurs in the filter bath, where in the tub contains granular media which functions to filter dissolved particles. The filter media used in the Water Treatment Plant is silica sand. The working principle of a water filter device with activated carbon for household purposes is that the filtering speed must be set according to the planning criteria (0,24 - 4,00 $\mathrm{m} / \mathrm{hr})$, the filter media consists of granular material $(0,21-0,86 \mathrm{~mm})$ which fills or is arranged in the inflow to the outflow. Water filter media that can be used for household use are activated carbon from a coconut shell. Activated carbon has a high adsorption (adsorption in the surface layer) so that it can decompose micro pollutant compounds lowering iron and manganese in the water. Keywords: Water Purifier, Activated Carbon, Household.

\section{Pendahuluan}

Kota Balikpapan oleh Badan Koordinasi Tata Ruang Nasional digolongkan sebagai pusat kegiatan nasional. Menilik pertumbuhan penduduk Kota Balikpapan yang cukup pesat tentu membutuhkan dukungan penyediaan air bersih yang cukup besar. Kebutuhan layanan air bersih dapat dipastikan terus

Volume 1, Nomor 2, 2019

ISSN 2657-1439 (Print), ISSN 2684-7043 (Online) meningkat, sejalan dengan laju pertumbuhan penduduk serta perbaikan tingkat kesejahteraan yang berdampak pada pergeseran standar dan mutu kehidupan penduduk.

Air merupakan kebutuhan dasar bagi kehidupan, kenaikan jumlah penduduk diikuti pula laju pemanfaatannya, beban pengotorannya juga bertambah 
cepat. Daya dukung lingkungan cenderung semakin menurun, ditunjukkan dengan makin banyak daerah aliran sungai yang kondisinya semakin memburuk, sehingga tidak bisa lagi menyimpan air dengan baik yang berakibat ketersediaan air baku makin berkurang. Pada sisi lain, kondisi sumber air, terutama sungai, cenderung makin tercemar baik karena limbah rumah tangga, limbah industri atau juga oleh penggunaan pestisida, insektisida dan usaha pertambangan yang tidak terkendali.

Sumber yang dapat dimanfaatkan dalam jumlah besar oleh IPA berasal dari Sungai, kekeruhan dan mikroorganisme menjadi penanganan utama. Berdasarkan data PDAM Kota Balikpapan (Desember 2011 - Februari 2012), Sungai yang saat ini dimanfaatkan, kekeruhan 20,50 - 73,30 NTU, total coliform 23 - > 2400 jumlah/100 ml. Hal tersebut sangat mempengaruhi kualitas air baku yang akan diolah menjadi air minum. Instalasi Pengolahan Air (IPA) merupakan unit produksi untuk merubah sifatsifat air sehingga layak dikonsumsi. Penyediaan air minum adalah kegiatan menyediakan air minum untuk memenuhi kebutuhan masyarakat agar mendapatkan kehidupan yang sehat, bersih dan produktif, sedangkan sistem penyediaan air minum merupakan satu kesatuan sistem fisik (teknik) dan non fisik dari prasarana dan sarana air minum. Unit produksi sistem penyediaan air minum berfungsi untuk mengolah air baku menjadi air minum. Untuk mencapai kualitas air yang sesuai dengan standar kualitas air minum tersebut, air baku diolah dengan proses pemisahan partikel kasar, proses pemisahan tersuspensi, proses pemisahan terlarut, proses netralisasi dan proses desinfeksi (Joko Tri, 2010).

Beban pengotoran pada sungai bertambah, mengakibatkan bertambahnya juga beban pengolahan pada IPA, sehingga kualitas air yang diterima oleh masyarakat terkadang menjadi menurun seperti berbau, berwarna dan keruh. Berdasarkan permasalahan di atas, maka dilakukan pengabdian kepada masyarakat mengenai sosialisasi dan pelatihan pembuatan alat penjernih air dengan media karbon aktif peruntukan rumah tangga.

Tujuan pengabdian kepada masyarakat ini, agar masyarakat mengetahui dan memahami prinsip kerja alat penyaring air peruntukan rumah tangga terutama pada warga RT 8 dan RT 9 Kelurahan Klandasan Ulu Kota Balikpapan, agar masyarakat mengetahui dan memahami prinsip kerja alat penyaring dengan media karbon aktif peruntukan rumah tangga, sehingga dapat membuat secara mandiri terutama pada warga RT 8 dan RT 9 Kelurahan Klandasan Ulu Kota Balikpapan.

Filtrasi adalah proses penyaringan partikel yang tidak terendapkan di sedimentasi melalui media berpori. Filtrasi diperlukan untuk menyempurnakan penurunan kadar kontaminan seperti bakteri, warna, bau dan Fe sehingga diperoleh air yang bersih Volume 1, Nomor 2, 2019

ISSN 2657-1439 (Print), ISSN 2684-7043 (Online) memenuhi standar kualitas air minum. Air yang keluar dari penyaringan biasanya sudah jernih dan proses tersebut merupakan proses akhir dari seluruh proses pengolahan dan penjernihan air. Filter dibedakan menjadi dua macam yaitu saringan pasir lambat dan saringan pasir cepat (Joko Tri, 2010).

Saringan pasir lambat merupakan saringan pasir yang pertama kali digunakan dan diterapkan pada lingkungan pedesaan, tetapi sekarang ini sudah jarang dipakai. Saringan pasir lambat tanpa melewati proses pengolahan pendahuluan (koagulasi, flokulasi, sedimentasi). Saringan pasir cepat digunakan untuk menyaring air yang telah mengalami pengolahan pendahuluan seperti koagulasi, flokulasi dan sedimentasi. Saringan pasir cepat diterapkan pada Instalasi Pengolahan Air yang dikelola oleh Perusahaan Air Minum (Budiyono, 2013).

Berdasarkan Reynolds dalam Asmadi (2011), perbandingan kecepatan filter, meliputi:

1) Saringan pasir lambat, $0,1-0,24 \mathrm{~m} / \mathrm{jam}$.

2) Saringan pasir cepat, $4-21 \mathrm{~m} / \mathrm{jam}$.

Media yang sering digunakan adalah pasir kuarsa karena mudah diperoleh dan ekonomis, media penyaring lain selain pasir kuarsa yang dapat digunakan adalah karbon aktif, athracite dan lain-lain. (Joko Tri, 2010). Media filter adalah bahan yang digunakan untuk filtrasi dan merupakan bagian dari filter yang menyebabkan efek filtrasi. Media filter terdiri dari material yang mengisi atau yang tersusun di dalam filter. Supaya air dapat melewati media filter, maka media filter harus mempunyai sistem pori-pori (Asmadi, 2011).

Pasir kuarsa merupakan media filter yang digunakan untuk pengolahan air kotor menjadi air bersih/ air minum. Pasir kuarsa merupakan hasil pelapukan batuan yang mengandung mineral. Hasil pelapukan kemudian tercuci dan terbawa oleh air atau angin yang terendam di tepi-tepi sungai, danau, laut. Pasir kuarsa berfungsi untuk menghilangkan sifat fisik seperti kekeruhan dan bau. Cadangan pasir kuarsa terbesar terdapat di Sumatera Barat, potensi lain terdapat di Kalimantan Barat, Jawa Barat, Sumatera Selatan, Kalimantan Selatan serta Pulau Bangka dan Belitung (Kusnaedi, 2010).

Berdasarkan Reynolds dalam Asmadi (2011), karakteristik ukuran media filter, meliputi:

1) Pasir kuarsa.

a) Ukuran $0,50-0,81 \mathrm{~mm}$.

b) Ukuran efektif $0,50 \mathrm{~mm}$.

2) Karbon aktif.

a) Ukuran 0,21-0,86 mm.

b) Ukuran efektif $1,00 \mathrm{~mm}$.

Pada proses pengolahan air bersih/ air minum dipakai karbon aktif dalam bentuk GAC (Granular Activated Carbon). Karbon aktif dimanfaatkan sebagai media filter pada filter media tunggal atau filter media ganda (Asmadi, 2011). 
Karbon aktif merupakan bahan penyerap (adsorben) yang paling banyak digunakan pada pengolahan air untuk menghilangkan rasa, bau dan warna yang tidak menyenangkan. Karbon aktif mempunyai sejumlah kapiler di dalam partikelpartikelnya. Permukaan karbon aktif yang bisa digunakan untuk adsorpsi (penyerapan bahan/ senyawa tertentu pada permukaan padat) terdiri dari luas penampang luar dan luas permukaan pori-pori/ kapilernya (Budiyono, 2013). Hanya dengan satu gram dari karbon aktif, akan didapatkan suatu material yang memiliki luas permukaan sebesar $500 \mathrm{~m}^{2}$, dengan luas permukaan yang sangat besar, karbon aktif sangat efektif menyerap zat terlarut dalam air, baik organik maupun anorganik (Kusnaedi, 2010).

Pada dasarnya karbon aktif dapat dibuat dari semua bahan yang mengandung karbon. Namun, kualitasnya sangat tergantung pada bahan dan proses pembuatannya. Berdasarkan Chemviron Carbon dalam Kusnaedi (2010), karakteristik karbon aktif dari berbagai jenis bahan baku, meliputi:

1) Karbon aktif dari tempurung kelapa.

a) Pori-pori mikro tinggi.

b) Pori-pori makro rendah, kekerasan tinggi, kadar abu $5 \%$.

c) Soluble ash dust tinggi, debu rendah.

d) Reaktivitas baik, rapat jenis $0,48 \mathrm{~g} / \mathrm{cc}$, bilangan iodin 1100 .

2) Karbon aktif dari batubara.

a) Pori-pori mikro tinggi.

b) Pori-pori makro sedang, kekerasan tinggi, kadar abu $10 \%$.

c) Soluble ash dust rendah, debu sedang.

d) Reaktivitas baik, rapat jenis $0,48 \mathrm{~g} / \mathrm{cc}$, bilangan iodin 1000 .

3) Karbon aktif dari lignite.

a) Pori-pori mikro sedang.

b) Pori-pori makro tinggi, kekerasan rendah, kadar abu $20 \%$.

c) Soluble ash dust tinggi, debu tinggi.

d) Reaktivitas lemah, rapat jenis $0,4 \mathrm{~g} / \mathrm{cc}$, bilangan iodin 600 .

4) Karbon aktif dari kayu.

a) Pori-pori mikro rendah.

b) Pori-pori makro tinggi, kadar abu $5 \%$.

c) Soluble ash dust medium.

d) Rapat jenis $0,35 \mathrm{~g} / \mathrm{cc}$, bilangan iodin 1000.

Karbon aktif dari tempurung kelapa sebagai bahan baku karbon aktif atas dasar kualitas yang dihasilkan lebih baik dari bahan lain.

Satu ton char (tempurung kelapa kering) akan menghasilkan 0,3 ton karbon aktif. Cara mengaktifkan karbon dengan memakai gas pengoksidasi seperti udara, steam atau karbon dioksida dan karbonasi bahan baku dengan memakai chemical agent seperti seng klorida atau phosphoric acid (Kusnaedi, 2010).

\section{Bahan dan Metode}

Metode kegiatan pengabdian kepada masyarakat yang dilaksanakan di Kelurahan Klandasan Ulu Kota Balikpapan adalah sebagai berikut:

1) Tahap persiapan.

a) Survey lapangan.

b) Pemantapan, penentuan lokasi dan sasaran.

c) Persiapan perlengkapan dan peralatan berupa tempurung kelapa, kaleng, batu bata, botol, selang, kapas.

d) Persiapan karbon aktif antara lain:

- Alat dan bahan meliputi tempurung kelapa, kaleng, batu bata.

- Prosedur kerja meliputi tahap 1 (satu) yaitu berikan beberapa lubang pada tutup kaleng, tahap 2 (dua) yaitu bersihkan tempurung kelapa dari serabut-serabut, tahap 3 (tiga) yaitu masukkan tempurung kelapa yang sudah dibersihkan dari serabut-serabut ke dalam kaleng, kemudian tutup rapat keleng tersebut, tahap 4 (empat) yaitu letakkan kaleng yang sudah ditutup rapat dan berisi tempurung kelapa di atas pembakaran, tahap 5 (lima) yaitu bakar sampai bara pembakaran hampir habis, tahap 6 (enam) yaitu bersihkan tempurung kelapa yang telah menjadi arang/ karbon aktif.

e) Persiapan alat penyaring air antara lain:

- Alat dan bahan meliputi botol, selang, kapas, karbon aktif.

- Prosedur kerja meliputi tahap 1 (satu) yaitu siapkan botol berukuran $600 \mathrm{ml}$ sebanyak 2 (dua) buah, tahap 2 (dua) yaitu lakukan pemotongan botol menjadi 2 (dua) bagian, hanya bagian atas botol yang digunakan, tahap 3 (tiga) yaitu bentuk untuk saluran masuk dan keluarnya air, tahap 4 (empat) yaitu masukkan karbon aktif setebal $5 \mathrm{~cm}$ ke dalam botol yang telah dibentuk, kemudian masukkan kapas setebal $5 \mathrm{~cm}$ di atas lapisan karbon aktif tersebut, tahap 5 (lima) yaitu lakukan pengujian alat penjernih air.

2) Tahap pelaksanaan.

a) Metode ceramah.

Metode ceramah ini dipilih untuk memberikan penjelasan tentang 
pembuatan alat penyaring air dengan media karbon aktif peruntukan rumah tangga.

b) Metode tanya jawab.

Metode tanya jawab ini sangat penting bagi peserta baik disaat menerima penjelasan dan pemahaman tentang pembuatan alat penyaring air dengan media karbon aktif peruntukan rumah tangga.

c) Metode simulasi.

Metode simulasi ini sangat penting diberikan pada peserta untuk memberikan kesempatan mempraktekkan materi ceramah yang diperoleh. Harapan peserta harus benar-benar menguasai meteri yang diterima mengenai pembuatan alat penyaring air dengan media karbon aktif peruntukan rumah tangga.

\section{Hasil dan Pembahasan}

Tahapan kegiatan ini meliputi:

1) Sosialisasi.

Sosialisasi dilaksanakan di halaman mushola RT 8/9 Kelurahan Klandasan Ulu Kota Balikpapan yang dihadiri oleh warga RT 8 dan RT 9 Kelurahan Klandasan Ulu Kota Balikpapan. Gambar 1 menunjukkan situasi sosialisasi berlangsung.

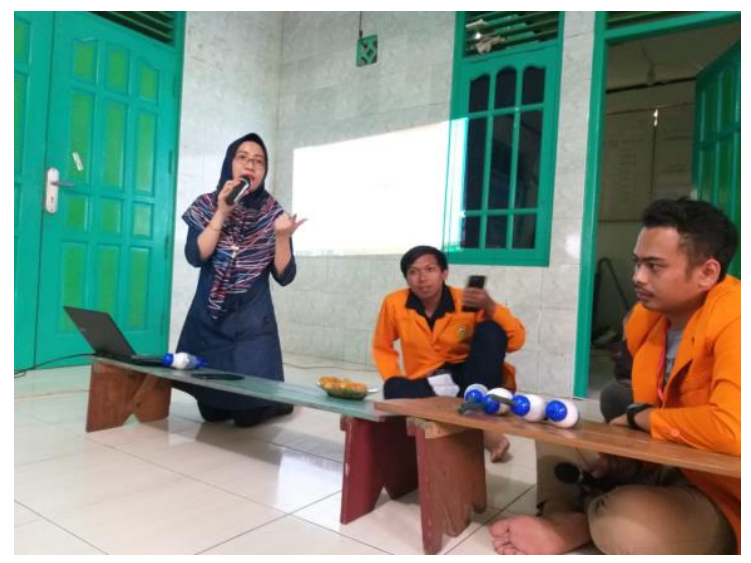

Gambar 1 Penyampaian Sosialisasi

Sosialisasi ini berisikan mengenai:

a) Prinsip kerja alat penyaring air.

Alat penyaring air peruntukan rumah tangga dibuat dengan prinsip kerja filtrasi yang merupakan suatu proses penyaringan dilakukan terhadap air hasil sedimentasi (pengendapan), berfungsi menghilangkan/ memisahkan flok halus yang tidak terendapkan/ lolos dari unit sedimentasi. Filtrasi terjadi di bak filter, dimana di dalam bak berisi media butiran-butiran (granular) yang berfungsi untuk menyaring partikel terlarut. Jenis penyaringan yang diterapkan pada Instalasi Pengolahan Air yaitu saringan pasir cepat (rapid sand filter). Penyaringan gravitasi dengan media butiran (granular) adalah tipe penyaringan yang paling banyak dijumpai dalam pengolahan air. Media butiran yang bisa dipakai adalah lapisan pasir kuarsa, kerikil, antrasit. Media penyaring yang digunakan pada Instalasi Pengolahan Air yaitu pasir kuarsa, karena harganya murah dan mudah didapatkan.

b) Prinsip kerja alat penyaring dengan media karbon aktif peruntukan rumah tangga.

- Pembuatan media karbon aktif dari tempurung kelapa sebagai media penyaring air.

Kota Balikpapan berbatasan dengan Selat Makassar pada bagian sebelah Selatan dan sebelah Timur, masyarakat yang tinggal di pesisir pantai memanfaatkan lahan dengan berkebun buah kelapa. Tempurung dari buah kelapa sawit yang sudah tua tentu saja sangat mudah ditemukan mengingat banyak masyarakat yang tinggal di pesisir pantai yang berkebun buah kelapa. Tempurung dari buah kelapa yang sudah tua merupakan salah satu limbah biomassa yang bisa dimanfaatkan sebagai bahan baku pembuat karbon aktif. Gambar 2 menunjukkan situasi pembuatan karbon aktif dari tempurung kelapa.
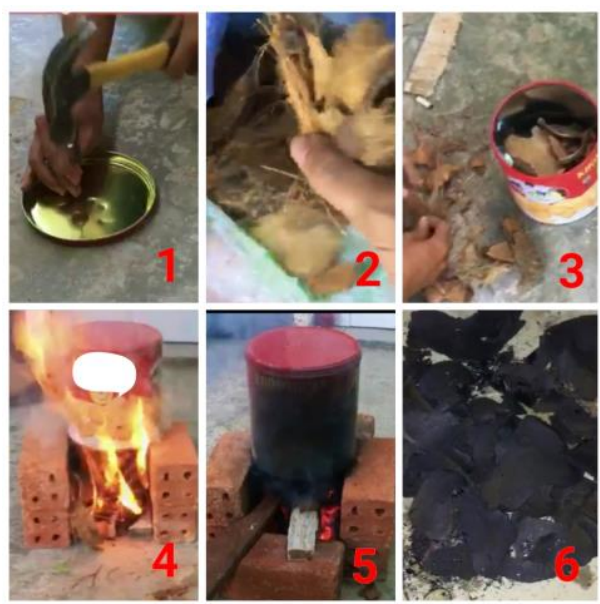

Gambar 2 Pembuatan Karbon Aktif dari Tempurung Kelapa

Di samping tempurung kelapa sangat mudah ditemukan dan merupakan pemanfaatan dari limbah biomassa, karbon aktif dari tempurung kelapa 
sebagai bahan baku karbon aktif atas dasar kualitas yang dihasilkan lebih baik dari bahan lain seperti batu bara, lignite dan kayu. Cara mengaktifkan karbon dengan memakai gas pengoksidasi seperti udara, steam atau karbon dioksida. Pada Gambar 2, tahap 4, menunjukkan cara mengaktifkan karbon, dilakukan pembakaran dengan cara wadah ditutup rapat, tutup diberi beberapa lubang kecil yang fungsinya untuk mengoksidasi.

- Pembuatan alat penyaring air peruntukan rumah tangga.

Alat penyaring air peruntukan rumah tangga tersusun atas media karbon aktif dan kapas di dalam botol yang dibentuk memiliki aliran untuk masuk dan keluarnya air. Kapas berfungsi sebagai penahan media karbon aktif sehingga tidak terikut aliran air keluar. Gambar 3 menunjukkan situasi pembuatan alat penyaring air.

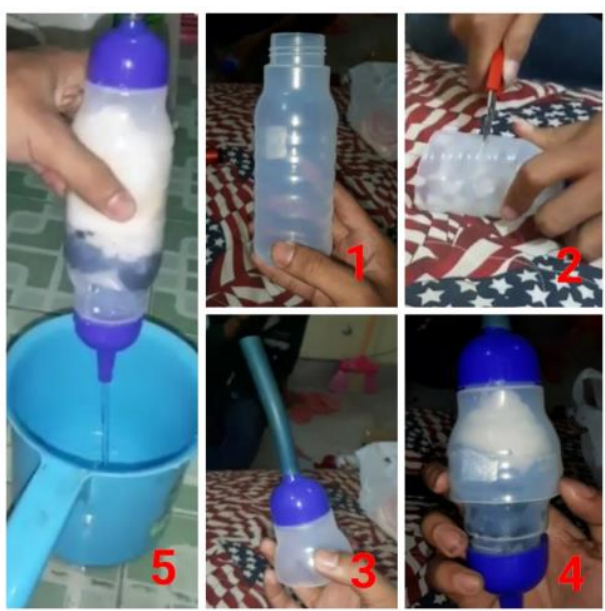

Gambar 3 Pembuatan Alat Penyaring Air

Pada proses penyaringan gravitasi, air mengalir dari atas ke bawah melalui media penyaring. Selama proses penyaringan berlangsung akan terbentuk lapisan kotoran yang tertahan pada media filter, pembentukan lapisan ini semakin lama akan semakin tebal sehingga terjadi pengurangan tekanan air di atas media filter, apabila air hasil penyaringan menggunakan alat menunjukkan kualitas yang keruh dan alirannya kurang lancar, menandakan alat penyaring air sudah banyak lumpur. Oleh karena itu, alat penyaring air perlu dibersihkan, dengan cara mengganti kapas dan mencuci media karbon aktif dengan air panas.

2) Pelatihan perakitan alat penyaring air.

Pada Gambar 4, memperlihatkan serah terima alat penjernih air dengan beberapa warga, diharapkan dengan pemberiaan alat penjernih air, nantinya masyarakat dapat mempraktekkan pembuatan alat penjernih air secara individu untuk keperluan dan kepentingan pribadi demi menciptakan kualitas air yang lebih baik.

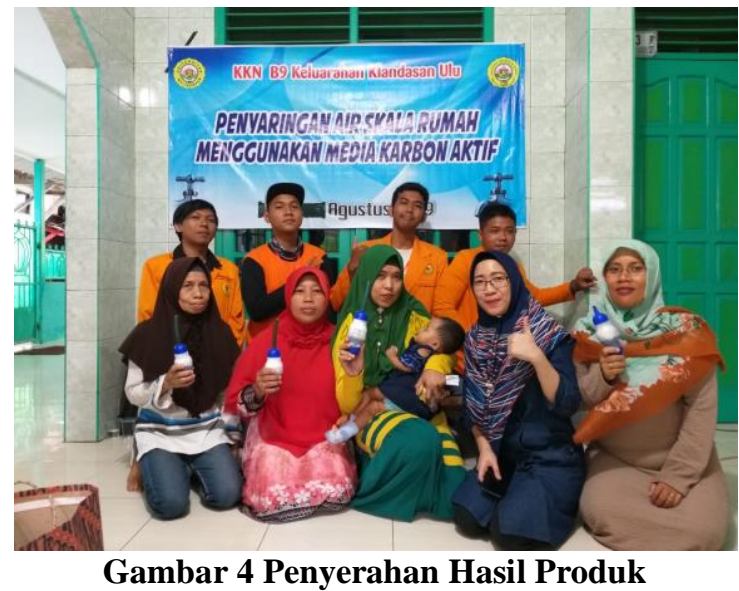

Pada Gambar 5, memperlihatkan serah terima alat penjernih air dengan Bapak Lurah, diharapkan dengan pemberiaan alat penjernih air, nantinya kelurahan dapat memfasilitasi dan menciptakan usaha kecil masyarakat (UKM) pada Kelurahan Klandasan Ulu.

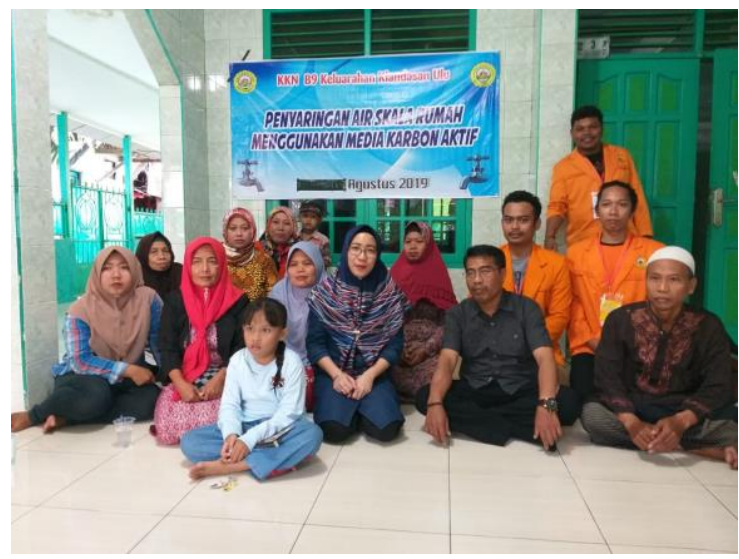

Gambar 5 Bersama Lurah Klandasan Ulu

\section{Kesimpulan dan Saran}

Kesimpulan kegiatan pengabdian kepada masyarakat ini yaitu:

1) Alat penyaring air peruntukan rumah tangga dibuat dengan prinsip kerja filtrasi yang merupakan suatu proses penyaringan yang diterapkan pada Instalasi Pengolahan Air yang dikelola oleh Perusahaan Air Minum. Filtrasi terjadi di bak filter, dimana di dalam bak berisi media butiran-butiran (granular) yang 
berfungsi untuk menyaring partikel terlarut. Jenis penyaringan yang diterapkan pada Instalasi Pengolahan Air yaitu saringan pasir cepat (rapid sand filter). Media penyaring yang digunakan pada Instalasi Pengolahan Air yaitu pasir silika. Beban pengotoran sungai bertambah, mengakibatkan bertambahnya beban pengolahan pada Instalasi Pengolahan Air, sehingga kualitas air yang diterima oleh masyarakat terkadang menjadi menurun, pembuatan alat penyaring air peruntukan rumah tangga dapat menjadi solusi untuk mendapatkan kualitas air yang lebih baik.

2) Prinsip kerja alat penyaring air dengan media karbon aktif peruntukan rumah tangga yaitu kecepatan penyaringan harus diatur sesuai kriteria perencanaan $(0,24-4,00 \mathrm{~m} / \mathrm{jam})$, media filter terdiri dari material dalam bentuk granular $(0,21-0,86 \mathrm{~mm})$ yang mengisi atau tersusun pada aliran masuk hingga aliran keluar. Media penyaring air yang dapat digunakan peruntukkan rumah tangga yaitu karbon aktif dari tempurung kelapa, disamping memanfaatkan dari limbah biomassa, mudah di dapat, juga karena kualitas yang dihasilkan dari proses penyaringan lebih baik dari bahan lain seperti batu bara, lignite dan kayu. Karbon aktif mempunyai daya adsorpsi (penyerapan pada lapisan permukaan) yang tinggi, permukaan partikel karbon aktif yang luas menjadi media penahan mikroorganisme yang bekerja secara biologi, mikroorganisme yang hidup dan menempel pada permukaan media penyaring dapat menguraikan senyawa mikro polutan, juga dapat menurunkan zat besi dan mangan yang ada di dalam air.

Saran untuk kegiatan selanjutnya adalah dilakukan kegiatan serupa untuk RT lain dan pada kelurahan lain di Kota Balikpapan guna terciptanya kualitas air yang lebih baik.

\section{Ucapan Terima Kasih}

Terima kasih kepada pihak-pihak yang membantu pengabdian kepada masyarakat ini, sehingga terlaksana dengan baik, kepada:

1) Lurah Klandasan Ulu Kota Balikpapan, atas kesediaan waktu untuk mengikuti kegiatan sosialisasi dan pelatihan pembuatan alat penyaring air dengan media karbon aktif peruntukan rumah tangga.

2) Ketua RT 8 dan warga RT 8 Kelurahan Klandasan Ulu, atas kesediaan waktu dan tempat untuk mengikuti kegiatan sosialisasi dan pelatihan pembuatan alat penyaring air dengan media karbon aktif peruntukan rumah tangga.
3) Ketua RT 9 dan warga RT 9 Kelurahan Klandasan Ulu, atas kesediaan waktu dan tempat untuk mengikuti kegiatan sosialisasi dan pelatihan pembuatan alat penyaring air dengan media karbon aktif peruntukan rumah tangga.

4) Mahasiswa Kuliah Kerja Nyata (KKN) Kelompok B9 Gelombang VI Tahun 2019 Universitas Balikpapan, yang membantu proses kegiatan ini dapat terlaksana, menyiapkan alat dan bahan yang digunakan pada pelatihan pembuatan alat penyaring air dengan media karbon aktif.

\section{Daftar Rujukan}

Asmadi, Khayan, Subaris Heru K. (2011). Teknologi Pengolahan Air Minum. Yogyakarta: Dosyen Publishing.

Budiyono, Sumardiono Siswo. (2013). Teknik Pengolahan Air. Yogyakarta: Graha Ilmu.

Joko Tri. (2010). Unit Air Baku dalam Sistem Penyediaan Air Minum. Yogyakarta: Graha Ilmu.

Joko Tri. (2010). Unit Produksi dalam Sistem Penyediaan Air Minum. Yogyakarta: Graha Ilmu.

Kusnaedi. (2010). Mengolah Air Kotor untuk Air Minum. Jakarta: Penebar Swadaya. 